\title{
Folate intake and the risk of endometrial cancer: A meta- analysis
}

\author{
Li Du' ${ }^{1,2}$, Yulong Wang ${ }^{2}$, Hang Zhang ${ }^{2}$, Hong Zhang ${ }^{1}$, Ying Gao ${ }^{2}$ \\ ${ }^{1}$ State Key Laboratory of Genetic Engineering and Institute of Biostatistics, School of Life Sciences, Fudan University, \\ Shanghai, China \\ ${ }^{2}$ Key Laboratory of Nutrition and Metabolism, Institute for Nutritional Sciences, Shanghai Institutes for Biological Sciences, \\ Chinese Academy of Sciences, Shanghai, China
}

Correspondence to: Ying Gao, email: yinggao@sibs.ac.cn

Keywords: folate, intake, endometrial cancer, risk, meta-analysis

Received: June 16,2016 Accepted: October 26, 2016

Published: November 08, 2016

\section{ABSTRACT}

Background: Folate may involve in various aspects of carcinogenesis. However, the relationship between folate intake and risk of many cancers, including endometrial cancer, is still inconclusive. We conducted a meta-analysis to systematically review the association.

Methods: Relevant studies were searched through three electronic databases (PubMed, Embase, and Web of Science) up to April 4, 2016. Population based prospective or case-control studies involving in investigating folate intake and risk of endometrial cancer were considered as eligible. Three investigators independently extracted data. Controversies were reconciled by discussing with a fourth investigator. Effect sizes of studies were pooled via a random effects model. Thereafter to explore the origin of heterogeneity among results of studies, a mixed effects model was employed with study design and dose of folate intake taken as covariates.

Results: Nine case-control studies and five cohort studies were included in the current meta-analysis. The result pooled from the highest category suggested a marginal negative association between folate intake and risk of endometrial cancer (OR=0.89 95\% CI: 0.76-1.05). Based on the mixed effects model, in the highest category, the risk showed an increasing trend along with increment of folate intake ( $5 \%$ risk increase per $100 \mu \mathrm{g} / \mathrm{d}, \mathrm{P}=0.01$ ).

Conclusion: A marginally negative association was observed between folate intake and endometrial cancer, which might subject to a threshold effect. More finely designed perspective studies or randomized trials are still needed to confirm the association.

\section{INTRODUCTION}

As a cofactor of the de novo synthesis of purine and thymidylate and the main supplier of one carbon unite, folate plays a critical role in keeping genetic and epigenetic stability of DNA [1]. The deficiency of folate will lead to a serial of abnormality, including breaks in the DNA strand, enhanced mutation rates, impairs in DNA repair mechanism and alternations of methylation status in genome scale [2].

Animal experiments and epidemiological studies had shown a link between increased risk of various cancer and folate deficiency [3-5]. However, folate may also motivate cell proliferation, which makes the relationship between folate intake and cancer risk more complicated $[6,7]$.

Some epidemiological studies suggested another story about the relationship of folate intake and cancer risk. A nested case-control study conducted in Sweden based on 226 cases and 437 matched controls suggested that the relationship between plasma folate concentration and the risk of colorectal cancer was in a bell-shaped manner [8]. Some other studies reported a positive association between folate and risk of cancers, such as breast cancer (odds ratio, OR: $1.19,95 \%$ CI: $1.01,1.41$ ) [9], prostate cancer (OR: 2.0; 95\% CI: 1.1, 3.7) [10], and 
ovarian cancer (relative risk, RR: $1.21 ; 95 \%$ CI: 0.94 , 1.63) [11]. Briefly, doubts about the role folate playing in carcinogenesis are emerging, at least for certain types of cancer, based on certain populations.

Being one of the most common gynecologic malignancy tumor, the endometrial cancer develops in over 200,000 women worldwide, deprives above 42,000 lives every year [12]. The relationship between folate intake and risk of endometrial cancer is still inconclusive. The OR's of studies range from 0.57 to 1.71 , with only few ones have statistical significant associations [13-26]. Therefore, we aimed to evaluate the association between endometrial cancer risk and folate intake, and explore the source of heterogeneity among studies, through systematic reviewing published articles.

\section{RESULTS}

\section{Search results}

The search process was presented in Figure 1. From PubMed, EMbase, and Web of Science with key words of "folate" paired with "cancer" and "endometrial", 5267 articles were screened. From references of articles and relevant reviews 579 more articles were identified. There were 1536 duplicates were removed and left 4297 articles. Among them, 4283 were excluded because they were based on animal or cell lines, or irrelevant. Fourteen studies were finally included in the current meta-analysis [13-26].

\section{Description of the included studies}

All studies identified were human based epidemiological studies focusing on folate intake and risk of endometrial cancer, with participants of postmenopause women. Five of 14 studies were perspective cohort studies. All five cohort studies provided dietary data from follow-up. The other nine were retrospective case-control studies, with four based on hospital and five based on population. The years of follow-up for cohort studies and duration of data collection after diagnosis for case-control studies were listed in Table 1. Eleven studies were conducted in Canada and USA, the other three were

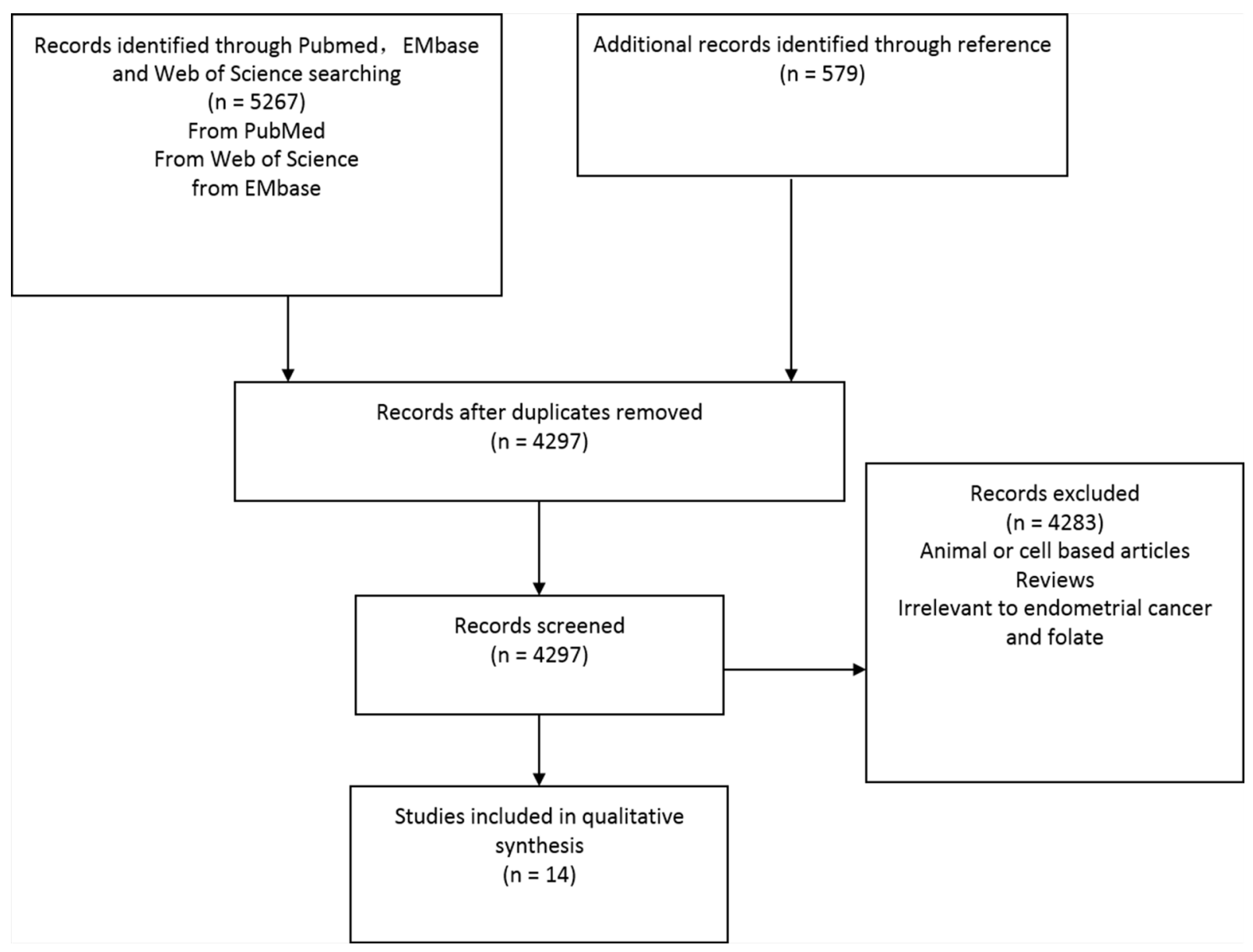

Figure 1: Identification process for eligible studies. 
Table 1: Characteristics of studies

\begin{tabular}{|c|c|c|c|c|c|c|c|c|c|}
\hline References & Year & $\begin{array}{c}\text { Geographic } \\
\text { regions }\end{array}$ & $\begin{array}{c}\text { Case- } \\
\text { controls } \\
\text { or } \\
\text { cohort } \\
\text { size }\end{array}$ & Age & $\begin{array}{c}\text { Food } \\
\text { frequency } \\
\text { questionnaire } \\
\text { (items) }\end{array}$ & $\begin{array}{c}\text { Folate } \\
\text { intake } \\
\text { calculation } \\
\text { method }\end{array}$ & $\begin{array}{l}\text { Time } \\
\text { frame* }\end{array}$ & Covariates & $\begin{array}{c}\text { Exclusion } \\
\text { of } \\
\text { hysterectomy }\end{array}$ \\
\hline \multicolumn{10}{|l|}{$\begin{array}{l}\text { Hospital- } \\
\text { based case- } \\
\text { control }\end{array}$} \\
\hline $\begin{array}{l}\text { Tavani } \\
\text { et al [19] }\end{array}$ & 2012 & $\begin{array}{c}\text { Italy\& } \\
\text { Switzerland }\end{array}$ & $454 / 908$ & $61.5^{\#}$ & 78 & IFCD & 10 years & $\begin{array}{c}\text { Age.Alc.B. } \\
\text { Edu.Engy.R.S }\end{array}$ & Not mention \\
\hline $\begin{array}{l}\text { Yeh } \\
\text { et al [22] }\end{array}$ & 2009 & USA & $541 / 541$ & $\begin{array}{l}27- \\
96\end{array}$ & 44 & USDA & 16 years & $\begin{array}{l}\text { Age.B.S. } \\
\text { Engy.H.R }\end{array}$ & Yes \\
\hline $\begin{array}{l}\text { Martinez } \\
\text { et al [17] }\end{array}$ & 2005 & Mexico & $85 / 629$ & $\begin{array}{l}18- \\
81\end{array}$ & 116 & Not mention & 2 years & $\begin{array}{c}\text { Age.Alc.B. } \\
\text { Engy.H.R }\end{array}$ & Yes \\
\hline $\begin{array}{l}\text { McCann } \\
\text { et al [16] }\end{array}$ & 2000 & USA & $\begin{array}{r}232 / \\
639\end{array}$ & $\begin{array}{l}40- \\
85\end{array}$ & 172 & USDA & 5 years & $\begin{array}{l}\text { Age.Alc.B. } \\
\text { Engy.H.R.S }\end{array}$ & Yes \\
\hline \multicolumn{10}{|l|}{$\begin{array}{l}\text { Population- } \\
\text { based case- } \\
\text { control }\end{array}$} \\
\hline $\begin{array}{l}\text { Biel } \\
\text { et al [21] }\end{array}$ & 2011 & Canada & $\begin{array}{l}506 / \\
981\end{array}$ & $\begin{array}{l}30- \\
79\end{array}$ & 124 & USDA $^{@}$ & 4 years & $\begin{array}{c}\text { (Age).Alc.B. } \\
\text { Engy.H.S.R }\end{array}$ & Not mention \\
\hline $\begin{array}{l}\text { Xu } \\
\text { et al [25] }\end{array}$ & 2007 & China & $\begin{array}{l}1204 / \\
1212\end{array}$ & $\begin{array}{c}30- \\
69\end{array}$ & 71 & $\begin{array}{c}\text { USDA\& } \\
\text { CDA }\end{array}$ & 6 years & $\begin{array}{c}\text { Age. } \\
\text { Alc.B.Edu. } \\
\text { Engy.H.R }\end{array}$ & Yes \\
\hline $\begin{array}{l}\text { Paynter } \\
\text { et al [18] }\end{array}$ & 2004 & USA & $\begin{array}{l}201 / \\
603\end{array}$ & $\begin{array}{l}30- \\
55\end{array}$ & 61 & USDA & 16 years & $\begin{array}{l}\text { (Age).Alc. } \\
\text { Engy }\end{array}$ & Not mention \\
\hline $\begin{array}{l}\text { Jain } \\
\text { et al [23] }\end{array}$ & 2000 & Canada & $\begin{array}{l}552 / \\
562\end{array}$ & $\begin{array}{c}40- \\
59\end{array}$ & 142 & USDA & 5 years & $\begin{array}{l}\text { Age.Alc.B. } \\
\text { Engy.H.R.S }\end{array}$ & Yes \\
\hline $\begin{array}{l}\text { Potischman } \\
\text { et al [15] }\end{array}$ & 1993 & USA & $\begin{array}{l}399 / \\
296\end{array}$ & $\begin{array}{l}20- \\
74\end{array}$ & 60 & Not mention & 5 years & $\begin{array}{l}\text { (Age).Alc.B. } \\
\text { (Engy).H.R.S }\end{array}$ & Yes \\
\hline \multicolumn{10}{|l|}{$\begin{array}{l}\text { Cohort } \\
\text { Studies }\end{array}$} \\
\hline $\begin{array}{l}\text { Liu } \\
\text { et al }{ }^{\top}[13]\end{array}$ & 2013 & USA & $\begin{array}{c}788 / \\
121700\end{array}$ & $\begin{array}{l}30- \\
55\end{array}$ & Not mention & USDA & 26 years & Age.B.H.R.S & Yes \\
\hline $\begin{array}{l}\text { Uccella } \\
\text { et al }{ }^{\top}[20]\end{array}$ & 2011 & USA & $\begin{array}{c}471 / \\
23356\end{array}$ & $\begin{array}{c}55- \\
69\end{array}$ & 126 & USDA & 17 years & $\begin{array}{l}\text { Age.Alc.B. } \\
\text { Engy.H.R.S }\end{array}$ & Yes \\
\hline $\begin{array}{l}\text { Uccella et } \\
\text { al }{ }^{\circledR}[20]\end{array}$ & 2011 & USA & $\begin{array}{c}71 / \\
23356\end{array}$ & $\begin{array}{c}55- \\
69\end{array}$ & 126 & USDA & 17 years & $\begin{array}{l}\text { Age.Alc.B. } \\
\text { Engy.H.R.S }\end{array}$ & \\
\hline $\begin{array}{l}\text { Kabat } \\
\text { et al [24] }\end{array}$ & 2008 & Canada & $\begin{array}{c}426 / \\
34748\end{array}$ & $\begin{array}{c}40- \\
59\end{array}$ & 86 & USDA & $\begin{array}{c}16.4 \\
\text { years } \\
\text { (average) }\end{array}$ & $\begin{array}{c}\text { Age. } \\
\text { Alc.B.Edu. } \\
\text { Engy.H.R.S }\end{array}$ & Yes \\
\hline $\begin{array}{l}\text { Jain } \\
\text { et al [14] }\end{array}$ & 2000 & Canada & $\begin{array}{c}221 / \\
56837\end{array}$ & $\begin{array}{l}30- \\
79\end{array}$ & 86 & USDA & $\begin{array}{c}10.3 \\
\text { years } \\
\text { (median) }\end{array}$ & $\begin{array}{l}\text { Age.B.Edu. } \\
\text { Engy.H.R.S }\end{array}$ & Not mention \\
\hline
\end{tabular}

*Years of follow-up for cohort studies and duration of data collection after diagnosis for case-control studies.

\# Median age.

(Continued) 
"Focusing only on type I endometrial cancer.

${ }^{\circledR}$ Focusing only on type II endometrial cancer.

( When estimating total folate intake, the amount of synthetic folic acid was multiplied by 1.7 in order to account for the greater bioavailability of synthetic folic acid.

Folate intake calculation method: IFCD=Italian food composition database, USDA=composition database from U.S

Department of Agriculture, $\mathrm{CDA}=$ composition database from China Department of Agriculture

Covariates: Age $=$ Age, $\mathrm{Alc}=$ Alcohol, $\mathrm{B}=\mathrm{BMI} /$ weight, Edu=Education, Engy=Total Energy, H=HRT/ERT use,

$\mathrm{R}=$ Reproductive factors, $\mathrm{S}=$ Smoking. (Age): matched on age. (Engy) Energy from carbohydrate calories.

conducted in China, Mexico, and Italy and Switzerland respectively. The intake of folate was all quantified by food frequent questionnaire. Though based on the same population, the study of Uccella et al [20] reported the OR of two different subtypes of endometrial cancer separately, thus both of them were adopted. Detailed characteristics of studies were listed in Table 1.

\section{Data quality}

Potential confounding factors including age, total energy intake, alcohol intake, and BMI were controlled or matched while estimating ORs or RRs. Twelve out of 14 studies each had a sample size of more than 200 cases [12$16,18-25]$. The sample size of the other two articles were 85 and 71 cases respective $[17,20]$. Thirteen of 14 studies calculated the intake of folate directly from food frequent questionnaires. When estimating total folate intake, Biel et al [21] multiplied the amount of synthetic folic acid by 1.7 before it was added to folate from food in order to account for the greater bioavailability of synthetic folic acid.

\section{Association between folate intake and risk of endometrial cancer}

A random effects model was used to pool the ORs of highest category versus the lowest $\left(I^{2}=59 \%\right.$, $P$ heterogeneity $=0.003$ ). The overall result suggested a marginal negative relationship between folate intake and the risk of endometrial cancer $(\mathrm{OR}=0.89 ; 95 \% \mathrm{CI}=$ 0.76-1.05; Figure 2). The OR pooled from case-control studies was statistically significant $(\mathrm{OR}=0.79 ; 95 \% \mathrm{CI}=$ 0.64-0.99), evidently apart from that summarized from cohort studies $(\mathrm{OR}=1.05 ; 95 \% \mathrm{CI}=0.9-1.21$; Figure 2$)$. From studies conducted in North America, the relationship was neutral $(\mathrm{OR}=0.92 ; 95 \% \mathrm{CI}=0.77-1.09$; Figure $3)$. Whereas studies conducted outside North America showed a significantly negative relationship $(\mathrm{OR}=0.73$; $95 \% \mathrm{CI}=0.58-0.91$; Figure 3 ). To assess the robustness of the relationship, we conducted a sensitivity analysis. If the weight of $\mathrm{Xu}$ et al [25] was decreased from $66.3 \%$ to $51.66 \%$, alias, the difference of weights between Xu et al and summation of the other two studies decreased $29.28 \%$, the association would alter to marginal significant $(\mathrm{OR}=$ $0.78 ; 95 \% \mathrm{CI}=0.62-1)$. If the weights of three studies were set equal, the estimation of effect size was still negative
$(\mathrm{OR}=0.87)$. However, it was not statistically significant $(95 \% \mathrm{CI}=0.63-1.18)$.

To explore the origin of heterogeneity among study results, in the highest category, we employed a mixed effects model with study design and dose of folate intake as covariates. The risk showed a significant increasing trend along with further increment of folate intake $(5 \%$ risk increase when the folate intake increases $100 \mu \mathrm{g} / \mathrm{d}$, $\mathrm{P}=0.01$ ). Meanwhile comparing to cohort studies, the mean lnOR of case-control studies was significantly lower $(\beta=-0.249, \mathrm{P}=0.002)$.

We also applied the mixed effects model to the second highest category. No significant publication bias was observed (Begg's test $\mathrm{P}=0.367$; Egger's test $\mathrm{P}=0.541$ ). The pattern of results was similar as that in the highest category, with a comparable increasing trend (6\% risk increase per $100 \mu \mathrm{g} / \mathrm{d}, \mathrm{P}=0.057$ ) and a more substantial difference of mean lnORs between different study designs $(\beta=-0.3666, \mathrm{P}<0.001)$.

When it comes to the third higher category, The $\mathrm{P}$ values for Begg's test and Egger's test were 0.638 and 0.22 respectively, suggested no significant publication bias. Because of the insignificant heterogeneity $\left(I^{2}=30.15 \%\right.$, Pheterogeneity $\left.=0.15\right)$, additional covariates were not necessary. Interestingly, if we incorporated the two covariates into the mixed effects model in the same way as the two higher categories, the trend of risk relation to intake of folate turned neutral ( $1 \%$ risk decrease per $100 \mu \mathrm{g} / \mathrm{d}, \mathrm{P}=0.899)$; yet the effect of study design remained relative constant, with an estimation of -0.21 and a $P$ value of 0.046 for the difference of mean lnOR between two subgroups.

\section{Publication bias}

Egger's test and Begg's test was performed in all 14 studies. Funnel plots were used for graphical representation. Significant publication bias was not observed, as suggested by Begg's test and Egger's test $\left(P_{\text {Begg }}=0.67\right), P_{\text {Egger }}=0.37$, Figure 4).

\section{DISCUSSION}

To explore the association between folate intake and the risk of endometrial cancer, we conducted this 
meta-analysis by including 14 independent studies. In the highest category, summarized by a random effects model, the folate intake showed a marginal negative association with the risk of endometrial cancer. Through a stratified analysis, a significant negative association was observed in studies conducted outside North America and case-control studies. Then we further explored the heterogeneity through a mixed effects model, taking dose of folate intake and study design as covariates. The model was applied to all three higher categories. The difference of mean $\operatorname{lnOR}$ between case-control studies and cohort studies kept numerically relative stable and statistically significant among all three categories. A positive trend between folate intake and endometrial cancer risk was observed in the two higher categories.

Folate is extensively involved in various kinds of biological processes. The impact of folate upon risk of endometrial cancer may be blurred by different roles folate plays. As an important cofactor in DNA synthesis and one carbon unit metabolism, folate may help to inhibit carcinogenesis through promoting DNA repair, decreasing DNA mutagenesis and preventing aberrant DNA methylation [27]. Observational studies and clinical trials about various kinds of cancer supported the negative relationship of folate intake and cancer $[3-5,28]$.

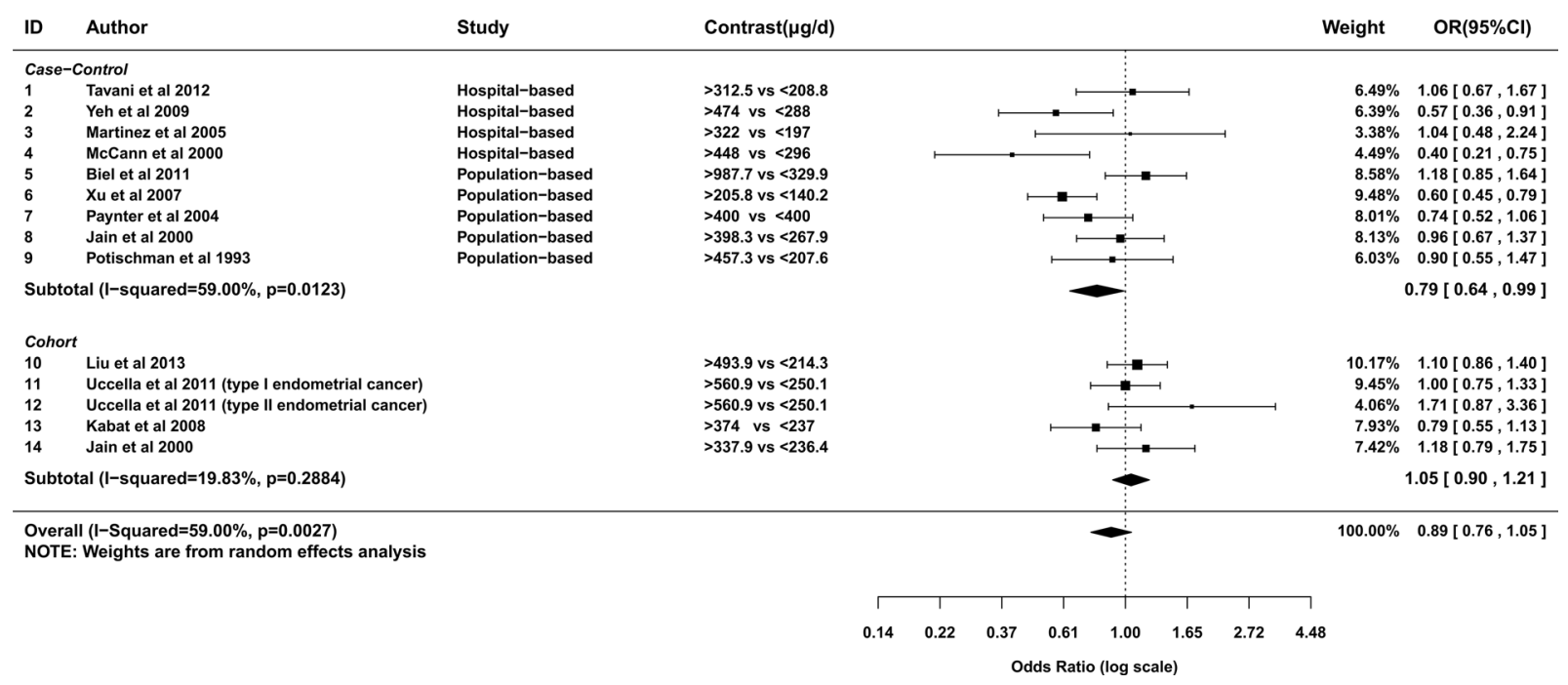

Figure 2: Meta-analysis of subgroup by design of studies.

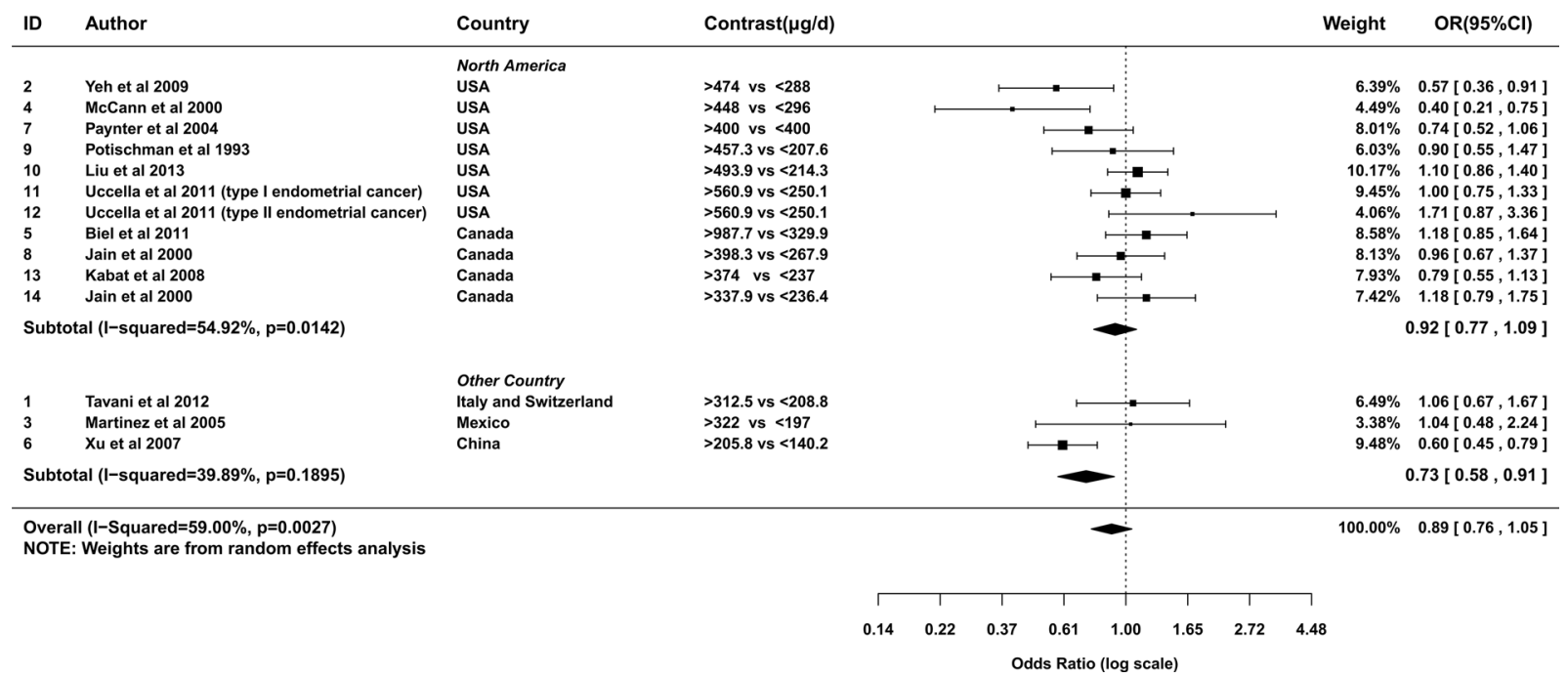

Figure 3: Meta-analysis of subgroup by geographic regions of studies. 
However, on other side, excess folate may also facilitate DNA synthesis in rapid proliferating cells, promote the growth and progression of already existed neoplasma [29]. Which is the rationale of anti-folate drug implementation in cancer therapy [2]. In addition, according to Troen et al [30], dietary folate intake, above a certain intake level, may enervate the cytotoxity of natural killer (NK) cell, an important part of nonspecific immune response system. Women in the lower tertile with folate intake $<233 \mu \mathrm{g} / \mathrm{d}$ and a supplement up to $400 \mu \mathrm{g} / \mathrm{d}$ had better immune function than those in the same tertile without supplement. However, for those had a dietary folate intake more than $233 \mu \mathrm{g} / \mathrm{d}$, an additional supplement of more than $400 \mu \mathrm{g} / \mathrm{d}$ would lead to impairments of the NK cell function [30].

Some study design related factors could affect the outcomes of studies and have impact on the pooled OR. First, comparing to the estrogen dependent Type I, type II endometrial cancer is often related to p53 mutations, which are associated with DNA damage and abnormal cell proliferation. Therefore patients may be more susceptive to folate intake alternations [20]. However, the majority of studies included in our meta-analysis failed to distinguish two subtypes for patients, which increased the heterogeneity among subjects and decreased the power of detecting difference. Besides, the proportion of two subtypes may be different in different populations. Thus it may also increase heterogeneity of outcomes among studies. Second, folate from natural food and fortification had different effects in 13 of 14 studies. Folate is mainly fortified in the form of folic acid, a more stable analogue with significant higher bioavailability [31]. In North America, the average folic acid intake is about $400 \mu \mathrm{g} / \mathrm{d}$ [32], approximately twice the amount of folate from natural food. Thus the indiscrimination the two source of folate would lead to an underestimation of folate intake and a deviation in the estimation of effect size, especially for 9 studies conducted after the initiation of mandatory fortification in North America. Therefore, to confirm the association between folate intake and risk of endometrial cancer, studies being able to control the modification effect of more factors, including but not limited to those mentioned above, are still urgently needed.

The counterbalancing of folate may also lead to a threshold effect, which might be helpful to explain the positive trend of risk along with further increase of folate intake. Song et al [33] observed a dose-response positive relationship of folate supplement and risk of

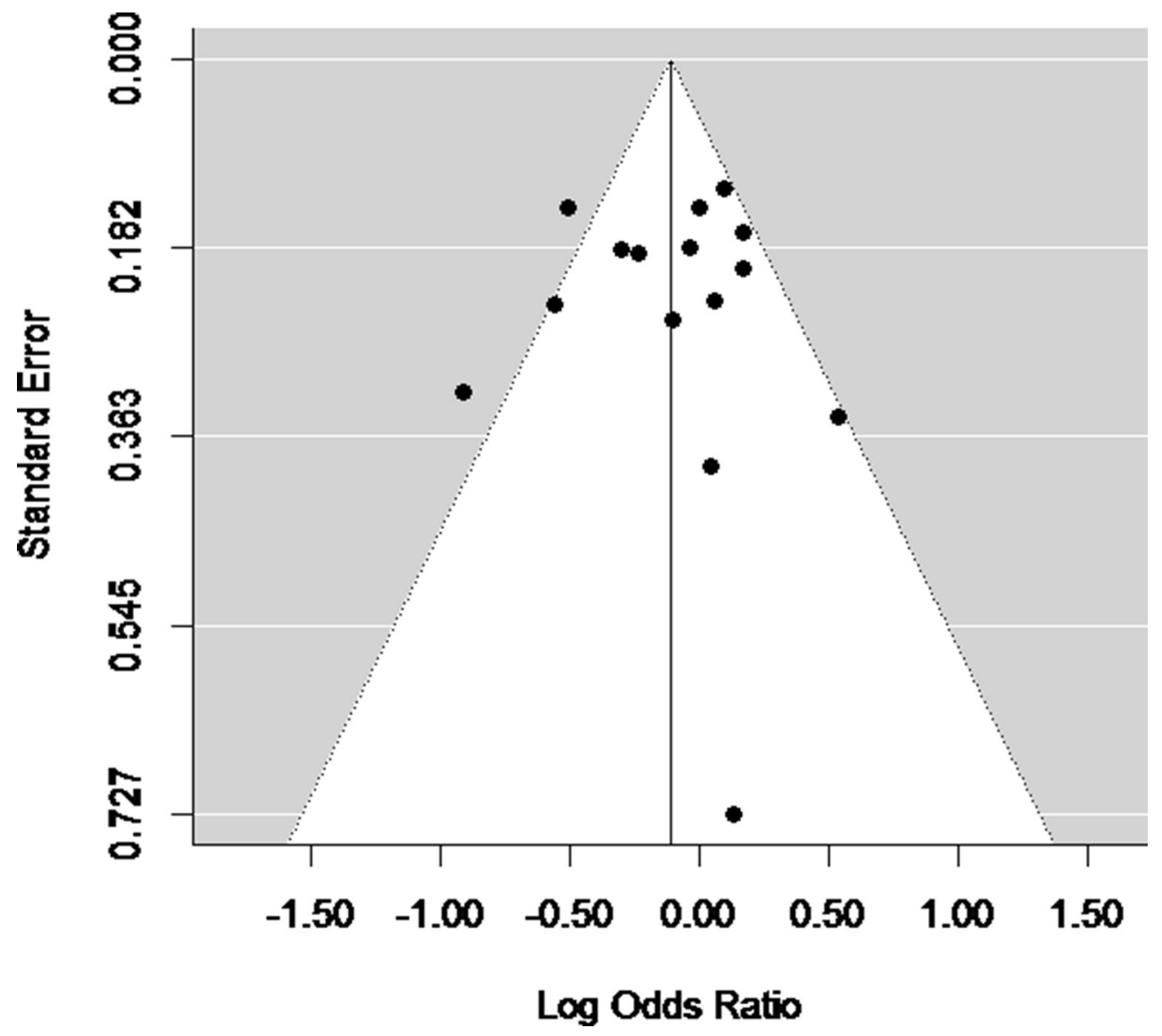

Figure 4: Funnel plot (with pseudo 95\% CIs) of all included studies. 
colorectal cancer in mice. To address the effect of large increase of folate intake [median $(95 \% \mathrm{CI})$ of plasma folate concentration: from $12.5(11.8,12.9)$ in NHANES to $32.2(30.1,33.8) \mathrm{nmol} / \mathrm{L}$ in NHANES III] on colorectal cancer after the fortification [32], Mason et al collected the incidence rate of two independent populations from USA and Canada respectively [34]. Both populations experienced a persistent decreasing of incident ratio in decades until mid1990s. However, the downward trend reversed abruptly thereafter. For USA it climaxed in 1998, for Canada in 2000, and kept at an incidence of 40 to 60 per million higher than that of 1996. By contrast, in this meta-analysis, the positive trend could not be observed in the $3^{\text {rd }}$ highest category, was marginally significant in the $2^{\text {nd }}$ highest category, became significant in the highest category.

In the current study, a negative association between folate intake and risk of endometrial cancer was observed in case-control studies. Since the difference of mean $\operatorname{lnOR}$ between case-control studies and cohort studies kept significant and relative stable among all three categories, recall bias inherited in the retrospective study might contribute to that deviation. When patients recalling their dietary, they tended to underestimation of folate intake and overestimation of protective effect of folate, especially for five population-based case-control studies.

Interestingly, a negative association was also observed in studies conducted outside North America. The sensitive analysis showed that the association was with moderate robustness. However, till now, through a comprehensive literature search there are still only three eligible studies identified. What's more, all three studies are retrospective study, thus they may also subject to the recall bias. Which weakened the solidity of conclusion, and is a major limitation of this meta-analysis.

This meta-analysis has some advantages. The mixed effects model enabled us to evaluate the effect size of covariates separately. By incorporating dose of folate intake into model, we could explore variation trend of the association. By taking study design as covariates, we could control the effects of study design, which is always a primary concern.

In conclusion, our meta-analysis suggested a marginal negative relationship between endometrial cancer risk and folate intake. The effect of folate may have a threshold effect. To illuminate the relationship of folate and endometrial cancer, more finely designed cohort and randomized clinical studies are needed. Moreover, subtype of endometrial cancer and source of folate need to be considered.

\section{MATERIALS AND METHODS}

\section{Literature search}

The process of the meta-analysis in this article was complied with the Preferred Reporting Items for Systematic Reviews and Meta-Analysis Statement
(PRISMA) issued in 2009 [35]. We systematically searched all human studies about folate intake and the risk of endometrial cancer up to August 31, 2016 from PubMed (http://www.ncbi.nlm.nih.gov/pubmed), EMbase (http://www.embase.com), and Web of Science (http:// www.webofknowledge.com). The references of studies and relevant reviews were also checked.

The key words for searching were as following: ("folate" OR "folic" OR "folacin") OR ("pteroyll-glutamic acid" OR "pteroyl-1-glutamate" OR "pteroylmonoglutamic acid")) paired with (("endometrial neoplasm") OR (("malign" OR "cancer" OR "carcinoma" OR "tumor") AND ("endometrial" OR "corpus uterine" OR "uterine")).

The inclusion criteria for studies are as following:

(i) The research was a human based case-control study, prospective study or clinical trial.

(ii) The interests of article included investigating the association between folate intake and risk of endometrial cancer.

(iii) The effect size (hazard ratio [HR], odds ratio $[\mathrm{OR}]$, or risk ratio $[\mathrm{RR}]$ ) and their confidence intervals (CIs) were available.

The exclusion criteria were as following:

(i) Studies based on cell lines or animal.

(ii) The article is not written with English.

(iii) Reviews, case-report, editorials or commentaries.

Three investigators ( $\mathrm{Li} \mathrm{Du}$, Yulong Wang and Hang Zhang) identified eligible articles independently according to the aforementioned criteria. Controversies on article inclusion among the three reviewers were resolved through discussing with a fourth investigator (Ying Gao).

\section{Data extraction and quality assessment}

Data on the study design, country, sample size, age, food frequency questionnaire items, time frame, exclusion of hysterectomy together with folate intake level of each category, effect size (OR for case control study, RR for cohort study), and $95 \%$ CI were collected. If crude OR or RR was reported together with multivariable adjustedeffect estimates, we chose the estimation that had been fully adjusted for the potential confounders.

The quality of studies was accessed by sample size and whether important confounders such as alcohol intake, total energy intake, body mass index and age had been adjustment for.

\section{Statistical analysis}

All statistical analyses were performed with R, version 3.1.2 (Package metafor). The primary outcome was defined as odds ratio (OR). Thus risk ratios (RR) together with their variance were converted to lnORs for further analysis [26]. Heterogeneity across studies was accessed according to the Cochrane $Q$ statistic and $I^{2}$ statistic. As long as the $\mathrm{P}$ value for heterogeneity was smaller than 
0.05 or the $I^{2}$ statistic was greater than $25 \%$, results of studies were considered as significantly heterogeneous and a DerSimonian and Laird random effects model was used to pool the results $[36,37]$. Otherwise the classical fixed effect model was employed. Modification effects of study design and countries (with or without mandatory folic acid fortification) were explored by stratified analysis. Countries with mandatory folic acid fortification include Canada and USA. Due to the limited number of studies conducted outside North America, to assess the robustness of the relationship, a sensitivity analysis was conducted by adjusting the weights of studies.

To explore the origin of heterogeneity among studies, a mixed effects model was applied to three higher categories as most of candidate studies were in quartile. Since the mandatory folic fortification in North America had led to a substantial difference in folate intake of populations in different country, the dose of folate intake, as well as study design were chosen as covariates of model $[38,39]$. Within every study, the mean folate intake in each category was estimated by method proposed by Chene and Thompson [40].

If the population on which a study based was divided into less than four categories, for instance, in tertiles, the two lnORs were allocated for pooling results of the highest and the second highest category. At the second highest category, study of Randi et al [18] was excluded because the population was divided into two quantiles. Then at the third highest category, the research of Martinez et al [17] with only 3 categories was also excluded.

The results of every study in all the models above were negative variance weighted. Publication bias was detected by Egger's test and Begg's test, then graphically represented by funnel plots.

\section{ACKNOWLEDGMENTS}

We thank Jie Liu from Shanghai Institutes for Biological Sciences for her help in search strategy consultation.

\section{CONFLICTS OF INTEREST}

The authors have no conflicts of interest to declare.

\section{FINANCIAL SUPPORT}

This research was supported by the 100 talented plan of Chinese Academy of Sciences (Ying Gao), the National Key Research and Development Plan (2016YFD0400200) (Ying Gao), and National Natural Science Foundation of China (11371101)(Hong Zhang).

\section{Author contributions}

The authors' responsibilities were as follows: Ying Gao and $\mathrm{Li} \mathrm{Du}$ conceived the idea and designed the study strategy; Li Du, Yulong Wang and Hang Zhang: summarized the data and conducted the data analyses and all authors contributed to the data analysis and writing and revision of the manuscript. The authors declared no conflicts of interest.

\section{REFERENCES}

1. Choi S-W, Mason JB. Folate and carcinogenesis: an integrated scheme1-3. The Journal of nutrition. 2000; 130:129-132.

2. Smith AD, Kim Y-I, Refsum H. Is folic acid good for everyone? The American journal of clinical nutrition. 2008; 87:517-533.

3. Kim Y-I. Folate and carcinogenesis: evidence, mechanisms, and implications. Journal of Nutritional Biochemistry. 1999; 10:66-88.

4. Giovannucci E. Epidemiologic studies of folate and colorectal neoplasia: a review. The Journal of nutrition. 2002; 132:2350S-2355S.

5. Mason JB. Folate consumption and cancer risk: a confirmation and some reassurance, but we're not out of the woods quite yet. The American journal of clinical nutrition. 2011; 94:965-966.

6. Kim Y-I. Role of folate in colon cancer development and progression. The Journal of nutrition. 2003; 133:3731S-3739S.

7. Ulrich CM, Potter JD. Folate supplementation: too much of a good thing? Cancer Epidemiology Biomarkers \& Prevention. 2006; 15:189-193.

8. Van Guelpen B, Hultdin J, Johansson I, Hallmans G, Stenling R, Riboli E, Winkvist A, Palmqvist R. Low folate levels may protect against colorectal cancer. Gut. 2006; 55:1461-1466.

9. Stolzenberg-Solomon RZ, Chang S-C, Leitzmann MF, Johnson KA, Johnson C, Buys SS, Hoover RN, Ziegler RG. Folate intake, alcohol use, and postmenopausal breast cancer risk in the Prostate, Lung, Colorectal, and Ovarian Cancer Screening Trial. The American Journal of Clinical Nutrition. 2006; 83:895-904.

10. Hultdin J, Van Guelpen B, Bergh A, Hallmans G, Stattin P. Plasma folate, vitamin B12, and homocysteine and prostate cancer risk: a prospective study. International Journal of Cancer. 2005; 113:819-824.

11. Tworoger SS, Hecht JL, Giovannucci E, Hankinson SE. Intake of folate and related nutrients in relation to risk of epithelial ovarian cancer. American journal of epidemiology. 2006; 163:1101-1111.

12. Amant F, Moerman P, Neven P, Timmerman D, Van Limbergen E, Vergote I. Endometrial cancer. The Lancet. 2005; 366:491-505.

13. Liu J, Hazra A, Giovannucci E, Hankinson S, Rosner B, De Vivo I. One-carbon metabolism factors and endometrial cancer risk. British journal of cancer. 2013; 108:183-187. 
14. Jain MG, Rohan TE, Howe GR, Miller AB. A cohort study of nutritional factors and endometrial cancer. European journal of epidemiology. 2000; 16:899-905.

15. Potischman N, Swanson CA, Brinton LA, McAdams M, Barrett RJ, Berman ML, Mortel R, Twiggs LB, Wilbanks GD, Hoover RN. Dietary associations in a case-control study of endometrial cancer. Cancer Causes \& Control. 1993; 4:239-250.

16. McCann SE, Freudenheim JL, Marshall JR, Brasure JR, Swanson MK, Graham S. Diet in the epidemiology of endometrial cancer in western New York (United States). Cancer Causes \& Control. 2000; 11:965-974.

17. SALAZAR-MARTINEZ E, LAZCANO-PONCE E, SANCHEZ-ZAMORANO L, GONZALEZ-LIRA G, ESCUDERO-DE LOS RIOS P, HERNANDEZ-AVILA M. Dietary factors and endometrial cancer risk. Results of a case-control study in Mexico. International Journal of Gynecological Cancer. 2005; 15:938-945.

18. Paynter RA, Hankinson SE, Hunter DJ, De Vivo I. No association between MTHFR $677 \mathrm{C} \rightarrow \mathrm{T}$ or 1298 $\mathrm{A} \rightarrow \mathrm{C}$ polymorphisms and endometrial cancer risk. Cancer Epidemiology Biomarkers \& Prevention. 2004; 13:1088-1089.

19. Tavani A, Malerba S, Pelucchi C, Dal Maso L, Zucchetto A, Serraino D, Levi F, Montella M, Franceschi S, Zambon A. Dietary folates and cancer risk in a network of case-control studies. Annals of oncology. 2012; 23:2737-2742.

20. Uccella S, Mariani A, Wang A, Vierkant R, Robien K, Anderson K, Cerhan J. Dietary and supplemental intake of one-carbon nutrients and the risk of type I and type II endometrial cancer: a prospective cohort study. Annals of oncology. 2011; 22:2129-2136.

21. Biel RK, Csizmadi I, Cook LS, Courneya KS, Magliocco AM, Friedenreich CM. Risk of endometrial cancer in relation to individual nutrients from diet and supplements. Public health nutrition. 2011; 14:1948-1960.

22. Yeh M, Moysich KB, Jayaprakash V, Rodabaugh KJ, Graham S, Brasure JR, McCann SE. Higher intakes of vegetables and vegetable-related nutrients are associated with lower endometrial cancer risks. The Journal of nutrition. 2009; 139:317-322.

23. Jain MG, Howe GR, Rohan TE. Nutritional factors and endometrial cancer in Ontario, Canada. Cancer Control. 2000; 7:288-296.

24. Kabat G, Miller A, Jain M, Rohan T. Dietary intake of selected $\mathrm{B}$ vitamins in relation to risk of major cancers in women. British journal of cancer. 2008; 99:816-821.

25. Xu W-H, Shrubsole MJ, Xiang Y-B, Cai Q, Zhao G-m, Ruan Z-x, Cheng J-r, Zheng W, Shu XO. Dietary folate intake, MTHFR genetic polymorphisms, and the risk of endometrial cancer among Chinese women. Cancer Epidemiology Biomarkers \& Prevention. 2007; 16:281-287.

26. Wang Y, Ji J, Liu Y-j, Deng X, He Q-q. Passive smoking and risk of type 2 diabetes: a meta-analysis of prospective cohort studies. PLoS One. 2013; 8:e69915.
27. Kim YI. Folate and colorectal cancer: An evidence-based critical review. Molecular nutrition \& food research. 2007; 51:267-292.

28. Duthie SJ. Folate and cancer: how DNA damage, repair and methylation impact on colon carcinogenesis. Journal of inherited metabolic disease. 2011; 34:101-109.

29. Kim YI. Folate, colorectal carcinogenesis, and DNA methylation: lessons from animal studies. Environmental and molecular mutagenesis. 2004; 44:10-25.

30. Troen AM, Mitchell B, Sorensen B, Wener MH, Johnston A, Wood B, Selhub J, McTiernan A, Yasui Y, Oral E. Unmetabolized folic acid in plasma is associated with reduced natural killer cell cytotoxicity among postmenopausal women. The Journal of nutrition. 2006; 136:189-194.

31. Konings EJ, Roomans HH, Dorant E, Goldbohm RA, Saris WH, van den Brandt PA. Folate intake of the Dutch population according to newly established liquid chromatography data for foods. The American journal of clinical nutrition. 2001; 73:765-776.

32. Pfeiffer CM, Caudill SP, Gunter EW, Osterloh J, Sampson EJ. Biochemical indicators of B vitamin status in the US population after folic acid fortification: results from the National Health and Nutrition Examination Survey 19992000. The American journal of clinical nutrition. 2005; 82:442-450.

33. Song J, Medline A, Mason JB, Gallinger S, Kim Y-I. Effects of dietary folate on intestinal tumorigenesis in the apcMin mouse. Cancer Research. 2000; 60:5434-5440.

34. Mason JB, Dickstein A, Jacques PF, Haggarty P, Selhub J, Dallal G, Rosenberg IH. A temporal association between folic acid fortification and an increase in colorectal cancer rates may be illuminating important biological principles: a hypothesis. Cancer Epidemiology Biomarkers \& Prevention. 2007; 16:1325-1329.

35. Moher D, Liberati A, Tetzlaff J, Altman DG. Preferred reporting items for systematic reviews and meta-analyses: the PRISMA statement. Annals of internal medicine. 2009; 151:264-269.

36. DerSimonian R, Laird N. Meta-analysis in clinical trials. Controlled clinical trials. 1986; 7:177-188.

37. Riley RD, Higgins JP, Deeks JJ. Interpretation of random effects meta-analyses. Bmj. 2011; 342:d549.

38. Van Houwelingen HC, Arends LR, Stijnen T. Advanced methods in meta-analysis: multivariate approach and metaregression. Statistics in medicine. 2002; 21:589-624.

39. Hedges LV, Olkin I. (2014). Statistical methods for metaanalysis: Academic press).

40. Chêne G, Thompson SG. Methods for summarizing the risk associations of quantitative variables in epidemiologic studies in a consistent form. American Journal of Epidemiology. 1996; 144:610-621. 